\title{
Limits to Leapfrogging: Issues in Transposing Successful River Basin Management Institutions in the Developing World
}

\author{
Tushaar Shah \\ Research Leader, Policy Institutions and Management; \\ lan Makin \\ Research Leader, Applied Information and Modeling Systems; \\ R Sakthivadivel \\ Senior Irrigation Engineer, Irrigation and Water Resources Programme; \\ International Water Management Institute, Colombo, Sri Lanka
}

\begin{abstract}
Many developed countries such as the USA, France, and Australia have evolved highly advanced and resilient institutional regimes for Integrated River Basin Management (IRBM); but this has taken decades or even centuries of gradual change to evolve. An issue which has held great appeal to policymakers, donors and social researchers is: might it be possible for the developing countries of today to do an institutional leap-frog', as it were, to quickly approach a stage at which developedcountry basin institutions find themselves today. This paper reviews the difficulties that developing countries might face in making such a leap-frog because of the vast and fundamental differences in four realities that matter in their institutional evolution: hydrological and climatic, demographic, socio-economic, and the reality of the way their water sectors are organised. The paper suggests that problems that evolved basin institutions in the developed world have successfully resolved-pollution, sectoral allocation, etc-are not the uppermost in the priorities of many developing country policymakers and people; and the problems that are uppermost to themsuch as groundwater over-exploitation, using irrigation to promote the livelihoods and food security of the poor-have either remained unresolved in the developed world, or are rendered irrelevant by their evolutionary process. There is thus the problem of 'contextual fit.' This does not mean that the experience of river basin management in the developed world is irrelevant; but it does mean that uncritical imposition of developed-country institutional models in developing-country river basin contexts may prove dysfunctional or even counter-productive.
\end{abstract}

\section{Bacḱkrop}

Management becomes important as a productive resource becomes scarce; and there is hardly a situation in which this is truer than in the case of the water resource. For a long time now, water policies of many emerging nations have been focussed on developing the resource; and optimising was directed at the efficiency of water infrastructure rather than water itself. As water has became increasingly scarce, optimising is now being increasingly directed to improving the productivity of water itself. Increasingly, the river basin is emerging as the unit of management of land, water and other natural resources in an integrated fashion. Many developed 
countries such as the USA, France, and Australia have evolved highly advanced and resilient institutional regimes for Integrated River Basin Management (IRBM); but this has taken decades-in Europe and centuries in the USA-of gradual change to evolve. An issue which has held great appeal to policymakers and social researchers is this:

Is it necessary that developing countries in Asia and Africa should take all that long in crafting such institutional regimes? Or might it be possible for them to do an "institutional leap-frog," as it were, to a stage at which developed country basin institutions are today?

A textbook case of institutional reform for IRBM in recent times has been the MurrayDarling basin in Australia, where sweeping changes have been made and enforced since 1990. And transferring the lessons of success in IRBM-from Murray-Darling to Mahaveli, and Mississippi to Mekong — has emerged as a growth industry.

This paper attempts a broad-brush approach to understanding the material differences in the contexts of the developed-country river basins, from where institutional models emerge, and the developing-country river basin context in which these are applied. The idea is not to undermine the significance of the lessons from success but to emphasise the need for sagacity and critical analysis in assessing what will work and what will not, given the differences in the context. The phrase "Institutional change" is used to describe how communities, government and society change recurrent patterns of behaviour and interactions in coping with water scarcity and its socio-ecological ill-effects. It involves understanding laws and rule-making, roles, policies and institutional arrangements at different levels. The over-arching premise is that the effectiveness of a pattern of institutional development is determined by at least four realities of a river basin: hydro-geological reality, demographic reality, socio-economic reality, and the organisation of the water sector. By implication, institutional arrangements that have proved effective with one set of these realities may require major adaptation before they become appropriate to the needs of a river basin context defined by an alternative set of these realities.

Integrated River Basin Management is a powerful idiom, and will increasingly dominate natural resource management discussion in the developed as well as developing world. In its broadest sense, a basin or catchment is visualised as

"an inter-connected machine or system which transforms natural inputs of solar energy, atmospheric precipitation, nutrients and other environmental factors, along with man-made inputs of labour, capital, materials and energy, into output products such as food, fibre, timber, building materials, fuels, minerals, natural vegetation and wildlife, recreational and aesthetic amenities, buildings and development sites, as well as water in desirable quality and quantity." (Burton 1986, cited in Hu 1999:324). 
River-basin management as a notion goes far beyond traditional land and water management and

"includes significant parts of land-use planning, agricultural policy and erosion control, environment management and other policy areas. It covers all human activities that use or affect fresh water systems. To put it briefly, $R B M$ is the management of water systems as part of the broader natural environment and in relation to their socio-economic environment." (Mostert et al 1999:3).

Institutional discussions on IRBM have tended invariably-and probably erroneously-to gravitate around three models of strategic organisations for managing river basins:

- the hydrological model, in which a river basin organisation/authority cutting across administrative boundaries, takes over all charge of water resource management;

- the administrative model, prevailing in many developing countries, in which water management is the responsibility of territorial organisations unrelated to hydrological boundaries; and

- co-ordinating mechanisms superimposed on the administrative organisations to achieve basin management goals.

Each has advantages and disadvantages: the hydrological model effectively deals with upstream-downstream issues that the administrative organisation is generally unable to deal with; however, hydrological organisations tend typically to focus on water and overlook land management issues. River Basin Commissions, as a hybrid, might combine the advantages of both, but at least in the developing country context, they often command little authority, and are therefore contined to lowest-common-denominator solutions (Mostert et al 1999). in many developing countries today, institutional reform for RBM is confined almost wholly to the creation of the basin-level organisation-the implicit assumption being that mere formation of the appropriate organisation will result in IRBM, an assumption whose validity has been repeatedly refuted.

In the developed world, the discussion has been much broader and has veered around initiatives in four aspects of natural resource governance:

[a] some mechanism for basin level negotiation and co-ordination fortified with adequate authority and resources, and a broad mandate considered appropriate to the basin's context;

[b] legal and regulatory reform

[c] redesigning economic instruments of policy (transfer prices, taxes, subsidies) in harmony with national policy goals: 
[d] redesign of economic institutions (including utilities, service providers, property rights; water markets, Irrigation Management Transfer to user organisations).

Countries like the USA have achieved, over long periods, high levels of integration even without a central basin organisation (see, for example, Svendsen 2000).

\section{Applying the lessons of the Murray-Darling to the developing world}

The Murray-Darling River system, as a recent case of accelerated institutional reform, has appropriately emerged as a model of institutional structure for IRBM. The basin encompasses over 75 percent of the State of New South Wales, 56 percent of the State of Victoria, all of the Australian Capital Territory, and small parts of Queensland and South Australia, a vast region of the south-eastern parts of the continent. Already, several case studies of the Murray-Darling are available; and it is not our intention to review these. In brief, the institutional innovations of the Murray-Darling basin management regime include:

[a] the Murray-Darling Ministerial Council as the top-level policymaking and co-ordinating mechanism; the Murray-Darling Basin Commission as the operating organisation; and several Catchment Management Agencies that are responsible for day-to-day management of water;

[b] a system of permits for diversions that encompasses all uses except the water needed for domestic use, livestock production, and irrigation of up to 2 ha which are recognised as a prior right (Hatton MacDonald and Young $2000: 10$ ), and exempted from legal as well as permit system;

[c] an effective cap on water diversions at 1993-94 levels of development to ensure adequate environmental supplies, accompanied by a system of volumetric licensing to users that raises the scope for large-scale water trade across states and sectors;

[d] consumption based, full-cost-recovery pricing (Hatton MacDonald and Young 2000: 14);

[e] a system of "salinity credits" that permits trade in salinity;

[f] explicit mechanisms for water allocation for environmental needs;

[g] a legal regime that separates water rights from land rights;

[h] privatisation of service providers such as Murray Irrigation Ltd and Victoria's Rural Water Corporation (Malano et al 1999).

The Murray-Darling RBM regime clearly represents a highly evolved form of institutional arrangement and effectively addresses all major problems that a mature river basin would face. As alluded to earlier, exploring whether developed-country basin institutions - particularly, Murray-Darling experience-can be replicated in a developing-country context has fascinated many researchers in recent years. An entire issue of Water International (vol. 24, no 4, 1999) was devoted to it in 1999. 
The results of these investigations have not been very encouraging. For example, Hu explored the applicability of Murray-Darling experience in the Chinese context and concluded negatively because of: (1) difficulty of co-ordinating authorities at different levels; (2) unclear ownership of resources; (3) small farming scales; and (4) poor education of resource users. (Hu $1999: 323$ ).

In a similar vein, Malano, Bryant and Turral (1999) ask: "Can Australian experiences be transferred to Vietnam?" Their conclusion is less emphatic than Hu's, but all their evidence suggests that it will be long before Vietnam becomes really ready for the Murray-Darling prescription; and that "context, hydrological and socio-economic, defines the detail and balance that is required.." (p: 313). The new water law of Vietnam contains provisions to adopt an integrated river basin approach. The World Bank as well as ADB have apparently held up funding to Vietnam until it forms the National Water Council to implement it. The Ministry of Agriculture and Rural Development, which is at present in charge of water, does not relish the responsibility of IRBM. The progress in stakeholder participation, another Murray-Darling prescription, has been slow to say the least. Farmers view irrigation provision as a government responsibility; even so, irrigation charges in Vietnam are high by Asian standards. Yet, presumably under donor pressure, the government tried to eliminate irrigation subsidies, but this was followed by massive popular unrest in 1998, whereupon, the Government had to restore the subsidies.

Can the Australian success in enforcing the "user pays" principle be transferred to the Solomon Islands? Hunt explored this issue in a recent study and concluded that such transfer "is not sustainably viable" on account of huge differences in political structures, national priorities, living standards, cultural traits, technological development, literacy levels, financial and infrastructure growth, and changemanagement competency. All these differences result in the absence of what Hunt calls a "contextual fit" between the policy development and the respective policy application environment. (Hunt 1999 : 302)

"If there is any conclusion that springs from a comparative study of river systems, it is that no two are the same" (Gilbert White cited in Jacobs 1999). Each river basin must differ from any other in a thousand respects; but that does not mean that lessons of success in one are of no value to another; it does mean though that uncritical "copycat" replication of successful institutional models-either by enthusiastic national governments or at the behest of enthusiastic donors-is a sure formula for failure. The history of institutional reform in developing-country water sectors is dotted with failures of such copycat reform.

Integrated river basin management is not a new idea, even in developing countries. India tried to transpose the TVA (Tennessee Valley Authority) model tried in the USA by constituting the Damodar Valley Authority, which was a resounding failure. Catchment management committees were established in China way back in the 1950s in some of the major river basins such as the Yangtse and Yellow River to plan and exploit water resources, generate electricity, mitigate flood damage, and provide facilities for navigation (Hu 1999: 327). But all these institutions shed their broad agenda and ended up focusing on irrigation, the purpose that was most central to their domains at those times. 
In Sri Lanka, a Water Resources Bcard was established as early as 1964 to promote integrated water resources planning, river basin and trans-basin development and to tackle water pollution; however, the Board never worked on its broad mandate and instead, took to hydrological investigations and-drilling tubewells. ${ }^{1}$ Such examples can be multiplied easily; the point is: in learning useful lessons from success cases for making meaningful reform in developing countries, it is important to understand critical differences between the two worlds that have material significance for what will work and what will not. We pose that, in understanding the applicability of institutional innovations, it is critical to take into account four types of material differences between the developed-and developing-country realities:
[a] hydrology and climate;
[b] demographics;
[c] socio-economics; and
[d] organisation of the water sector.

We briefly outline these material differences in the following sections.

\section{Hydrology of the developing world}

Historically, agriculture advanced early in arid climates such as those of Egypt and Iraq; but industrial development began early in the temperate and humid climates of Europe, North America and Japan. Some arid areas where significant wealth creation and accumulation has occurred-as in West Asia-are typically rich in mineral and oil resources. Today, however, the bulk of the developing world, where rainfall tends to be low and water scarcity is a major emerging constraint to progress is in the arid or semi-arid ${ }^{2}$ parts of the world. Figures 1 and 2, showing the global distributions of mean annual rainfall and potential evapotranspiration, help to illustrate some major climatic differences between developed countries (mostly in the temperate latitudes) and developing countries (mostly in the tropical and sub-tropical regions).

Sutcliffe (1995) pointed out that developing countries also happen to be concentrated in parts of the world with more extreme climates when compared . to the regions occupied by today's developed countries. Figure 1 illustrates the

\footnotetext{
'Another round of reform has just begun in Sri Lanka. In 1990, a draft law made provision for bulk water allocation and included the establishment of a National Water Resources Council to do what the Water Resources Board could not; but the law could be submitted to the Parliament only in 1995 for the lack of consensus in the cabinet as well as amongst the myriad agencies dealing with water (Birch and Taylor 1999:331).
}

${ }^{2}$ Referring to regions like India and West Africa, which are humid for a small part of the year but arid during the rest of the year. 


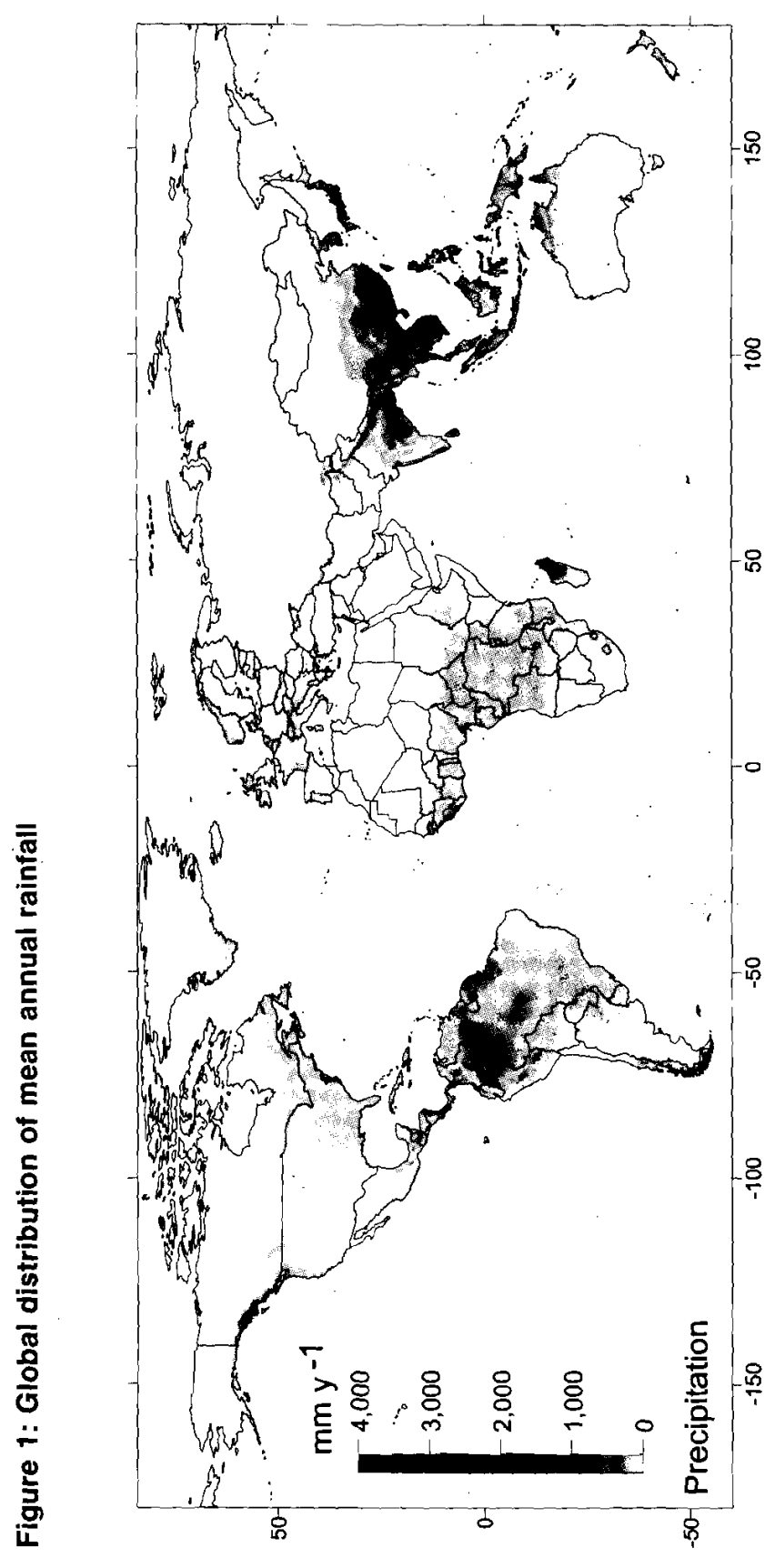




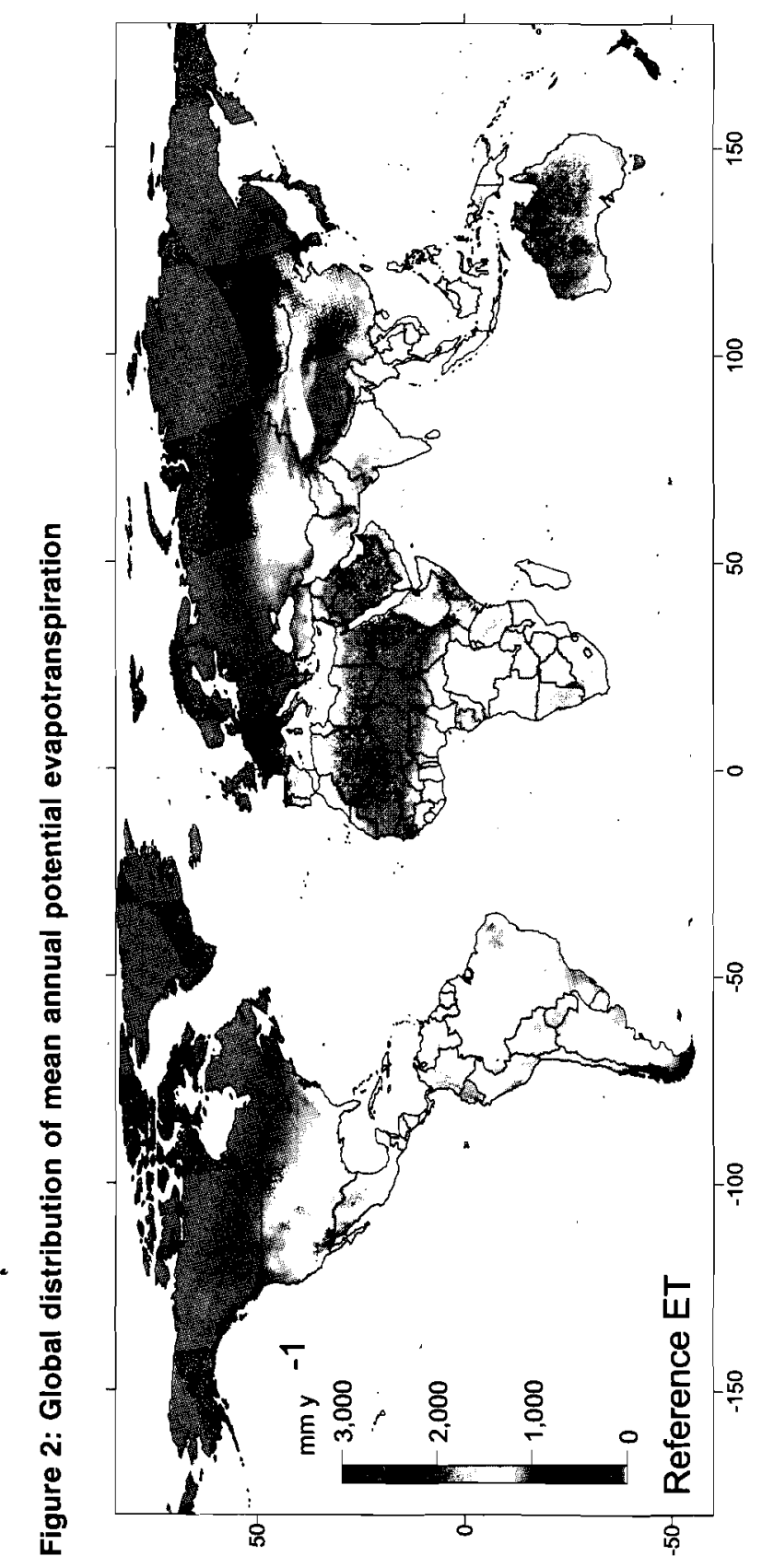

96 
enough of it from evapotranspiration to last from October until April-May, the months that mark the period of highest water stress. Botswana receives all of its 350-500 $\mathrm{mm}$ rainfall during November-March, the period which also coincides with the highest evaporation, resulting in little or no runaff (Sutcliffe 1995: 69).

Humid areas typically have higher stream densities than are found in the arid and semi-arid areas, which means that, ceteris paribus, a higher proportion of precipitation in the arid and semi-arid areas runs off in sheet flow before forming into streams, and is thereby subject to higher ET (evapotranspiration) losses (Figure 2). Other things also are not quite the same; the developing worldespecially, South Asia and much of Africa-around the tropics has higher mean temperatures for more of the year than the developed world. And, for equivalent levels of precipitation, runoff and the need for irrigation tends to be greater in arid and semi-arid areas than in humid areas (Sutcliffe 1995:64).

The climate and hydrological conditions, combined with demography (discussed in the following section), explain why decentralised institutions for water management have historically evolved in many parts of the developing world. The profusion of small tanks in India's southern peninsula and Sri Lanka can be viewed as the response of communities in the catchment areas to stake their claim on their rainfall. Even today, one collective maintenance task carried out by many south Indian tank communities before the start of the monsoon is cleaning and deepening of the channels that feed rainwater runoff to their tanks. Village people here recognise that if they do not capture runoff in artificial streams, most of it will be lost before it reaches their tanks.

\section{Demographics}

Many parts of the developed world have extreme climates too; however, over time, population and urbanisation in these parts have tended to concentrate in wet areas or on downstream reaches of rivers near coastal areas, where water can be supplied through large-scale diversion structures. As Figure 3 shows, except in Europe, most of the developed countries have low population densities throughout, with urban agglomerations near the coasts and rural population along rivers or irrigation systems. Here, the competition is for large accumulated bodies of "diverted water." Since catchment areas have relatively sparse populations, the downstream water-harvesting structures have large catchment areas that are virtually free from competition.

But this is not the case in some of the most densely populated regions of the world. In India, for instance, population density is high-approaching 600 persons per km² in the water-rich Ganga basin; and seldom less than 350400 even in semi-arid western India and hard-rock peninsular India. Population density is high both upstream and downstream of dams. The same is true for much of China; the North China plains have much less water than South China; but their population density is around the same. One might argue that the cause of intensive groundwater development in South Asia and China is that most people in these regions cannot be downstream of large dams; and by sinking tubewells people upstream are, in a sense, challenging the basic inequity inherent in the pattern of large irrigation projects that usurp the 


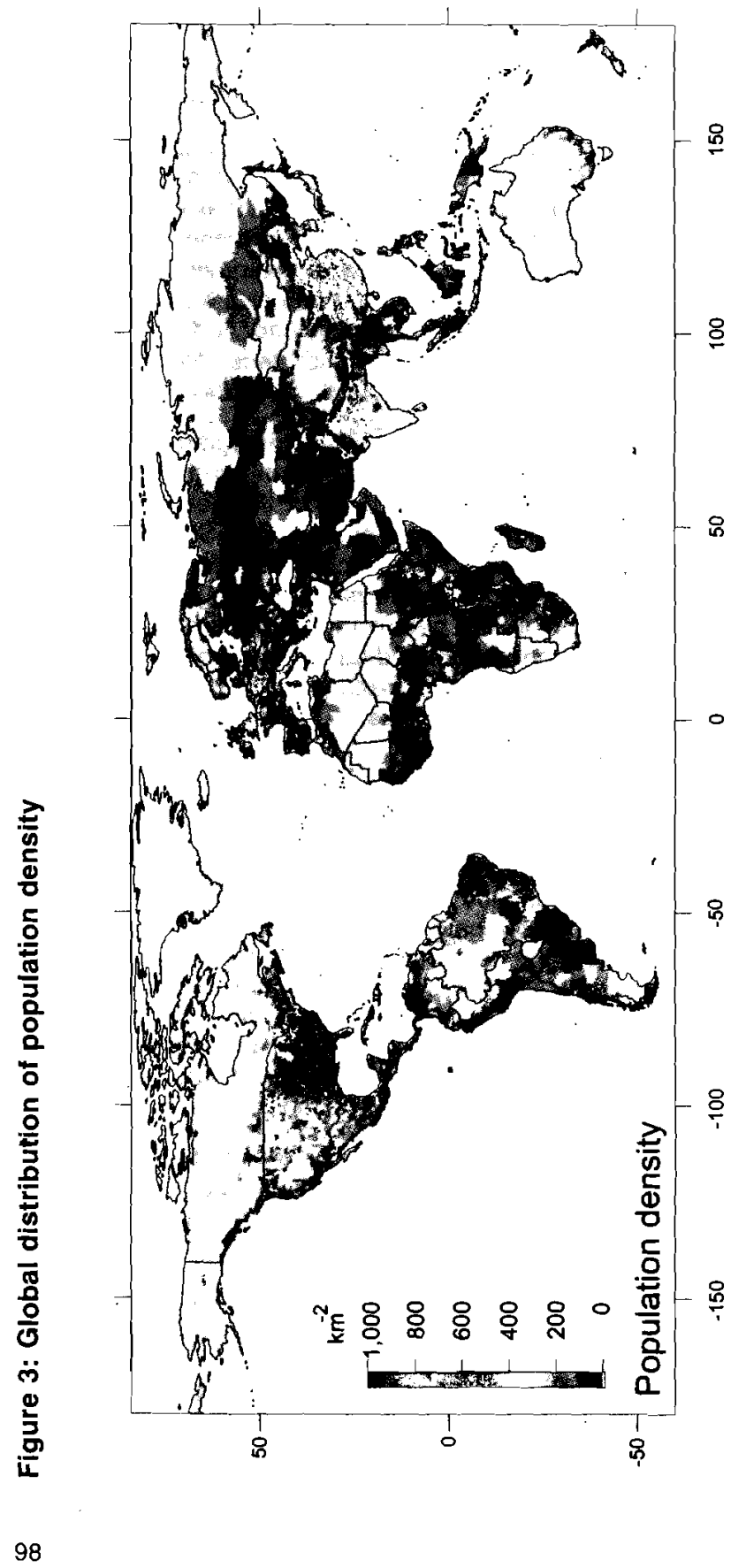


rainfall precipitation of populous upstream catchment areas to bequeath it to a small number of canal irrigators.

All these factors have had implications for the kind of water institutions that have evolved historically in the developed and developing world. For example, the system of rights based on riparian doctrine and on the doctrine of prior appropriation is alien to the cultures of many developing countries because the largest majority, by far, depend upon rainfall and local water-harvesting and storage structures. Riparian rights or prior allocation become operative only along the streams and rivers, where the bulk of the irrigators and water users tend to be concentrated in countries like the USA or Australia. But these make no sense, for example, for some 20 million persons pumping groundwater in South Asia; or the communities that use over 300,000 tanks in South India or 7 million ponds in China.

Because large proportions of the population in the developing world depend upon rain and on local storage, the people's notions of ownership and rights relate more easily to precipitation than large-scale public diversions. Egypt gets less than 10 percent of its water from rainfall; yet Egyptians consider the rainwater to be truly their own. In Asia, where population densities are commonly as high in the catchment areas of the basin, as along the stream and river channels, the implicit primacy of the right of communities over precipitation rather than over diversions is for example widely accepted. Indeed, in recent years, a popular slogan in western India is "rain on your roof, stays in your house; rain on your field stays in your field; and rain in your village stays in your village." In the Western countries, upstream-downstream conflicts are important because most water users think of users upstream as their rivais. In the World Water Forum that met at The Hague in March 2000, the slogan that the Delhi-based Centre for Science and Environment popularised was "Everyone Lives Downstream," which is eminently sensible if all or a majority of people in a basin depend for their water needs directly upon rainfall.

The IRBM discussion talks very little of the enormous amount of work on farming in the semi-arid tropics, done by national and international centres such as ICRISAT ${ }^{3}$. As the Global Water Partnership (2000: 25) notes: "Most water management, including the literature on IWRM, tends to focus on the 'blue water'4, thus neglecting rain and soil-water management. Management of 'green water' flows holds significant potential for water savings." This is because there is little real "dryland farming" of the indian and West African variety in the developed world; but making the best use of soil moisture is a critical issue in many African and Asian countries. Europe, Canada, New Zealand, and USA do have rain-fed farming; but this is not quite the same as dry tarming in western Rajasthan or sub-Saharan Africa; in many of these

International Crop Research Institute for the Semi-Arid Tropics

"Blue water" is water existing in bodies such as rivers or lakes, or pumped from aquifers. "Green water" is soil water extracted and transpired by plants. 
countries, favourable rainfall and climate conditions result in favourable soilmoisture regimes that make irrigation unnecessary for growing good crops.

The conventional notion of irrigation is one of controlled supply of water to meet the full scientific requirements of plants precisely when needed. But the irrigation that is most widely practised in South Asia and amongst smallholder farmers in Africa is supplemental irrigation designed to increase the productivity of "green water". Green water is the precipitation used directly for crop production and thus "lost" in evaporation; "blue water" pumped out from wells is as important in South Asia and North China as the part that flows into rivers and canal systems. ${ }^{5}$ This is quite unlike the situation in many developed country river basins. In these the bulk of economic water demands have been met from development of "blue" surface water and where, with the closure of these basins, the focus of basin management is on raising the productivity of blue surface water, largely without regard to green water.

Uniformly high population density, combined with unhelpful climate and hydrology, has a profound impact on the objectives of water management in developingcountry river basins. In recent years, IWMI's water accounting work (Molden and Sakthivadivel 1999: 58-60) has made much contribution to understanding water productivity in the basin context. ${ }^{6}$ Although IWMI's focus has been on productivity of water in agriculture, the framework can be easily generalised to develop a notion of basin-level water productivity in terms of a social welfare function for all stakeholders in a river basin constituting a basin community. Under this broad conception.

Basin welfare productivity of water $=$ Basin welfare/Available water

Water productivity understood thus could be enhanced by

[a] enhancing productivity in each use; and

[b] constantly reallocating water amongst alternative uses-irrigation, domestic, industrial, and environmental-so that the marginal

'This distinction between 'green' and 'blue' water is extremely important for developing countries in the semi-arid tropics. Terrestrial ecosystems are 'green water' dependent; aquatic ecosystems are blue water dependent (GWP 2000:24).

${ }^{6}$ Standard definitions used in IWMI water accounting work (Moiden and Sakthivadivel 1999) are: Gross inflow: total amount of water flowing into a domain from precipitation, surface and sub-surface sources; Net inflow: gross inflow +change in storage; Depletion: use or removal of water from a domain that renders it unavailable for or unsuitable for further use; Beneficial depletion: depletion that generates welfare; Process depletion: depletion in private economic uses; Non-process depletion : depletion in non-private, socially valued uses; Non-beneficial depletion: depletion that generates no economic or non-economic, private or social benefit; Committed water: outflow committed to other or downstream uses; Uncommitted outflow: outflows by default which are not used to create any value, private or social; Available water: net inflow -committed outflow-non-utilisable uncommitted outflow. Non-depletive uses: uses that create value without resulting in depletion. 
contribution to overall welfare by water allocated to all uses remains equal.

Using the IWMI water accounting framework, this welfare productivity measure can be written in several alternative ways to highlight the importance of different water use strategies ${ }^{7}$. But for highlighting the difference between developed and developing world, a useful way to write the welfare productivity ratio is:

Basin welfare/Available water $=\left[\right.$ Basin welfare/Diversions ${ }^{*}[$ Diversions/Available water]

In relatively water-abundant humid regions, with low population density in the catchment areas and dense human settlements near the coasts and along rivers, river-basin management seeks to maximise basin welfare productivity by increasing [Basin welfare/Diversions]. Allocation of diverted water amongst alternative uses is a crucial function in basin-level water management in such conditions. Here, reservoirs have large free catchments; and ET in catchment areas is often not high; therefore, the need for active human intervention to maximise [Diversions/available water] is not great.

In water-scarce tropical countries with high population density everywhere, as in South Asia and China, maximising basin welfare involves working on both the components. Increasing the productivity of diverted water is certainly important; but equally important is the need to maximise the proportion of precipitation and inflows into a basin that can be diverted before they are lost to non-beneficial depletion.

It is against this backdrop that we need to consider the growing mass movement for rainwater havesting and groundwater recharge in western India (Shah 2000). The region has amongst the highest windspeeds encountered anywhere in the world; it has high mean temperatures for nine months; rainfall varies between $300-800$ $\mathrm{mm} /$ year; and population density is $300-500$ per $\mathrm{km}^{2}$ in the catchment areas as well as in the downstream areas. The greatest challenge for rural communities is surviving the annual pre-monsoon drought in April and May, which is made infinitely more daunting by regular failure of monsoon rains. During the pre-monsoon months, leave alone growing crops; ensuring adequate drinking water for humans and cattle is the great challenge, especially in the catchment areas of river basins. While government investment programmes concentrated on building large reservoirs downstream to support irrigation and municipal water supplies to towns, the problems of the people living in the catchment areas remained unaddressed.

Disenchanted with government and public systems, NGOs and communities began to find their own solutions. The past decade has witnessed a massive popular awakening as the result of the efforts of NGOs like Tarun Bharat Sangh, Pradan, and of religious organisations such as the Swadhyaya Pariwar. This has taken the form of rainwater conservation and groundwater recharge work on a scale that governments or public agencies would not be able to manage. The basic motivation

${ }^{7}$ For example, by writing Basin welfare/available water $=($ Basin welfare/total depletion $){ }^{*}$ (total depletion/total diversion) ${ }^{*}$ ( total diversion/water available), we can signify alternative routes to water productivity. 
that has been driving the movement is to ensure availability of domestic water supply for two months before the monsoon and for one or two crop-saving waterings from wells; and there are indications that the movement may well meet this challenge.

Government agencies and scientists (hydrologists in particular) have been dubious about this mass movement, their argument being that rainwater harvesting structures upstream merely transfer water; these reduce the input into the reservoirs downstream, thereby reducing their productivity. But this argument does not resonate with the communities, especially in the upstream areas, which fail to see why they cannot meet their basic water domestic needs instead of feeding reservoirs to irrigate relatively small areas of paddy or cotton. In defence of this popular movement, the Delhi-based Centre for Science and Environment has asked: what does India need more-Irrigation or Drought-proofing? In reply, it has suggested that by a total rethink on "appropriate" river-basin management, India can trade drought-proofing over vast areas by sacrificing irrigation of small areas.

It has also adduced evidence to show that diverting rainwater in a large number of small water-harvesting structures in a catchment captures and stores more of the scarce precipitation, closer to the communities in these parts of the world, than having a large reservoir downstream (Agarwal 2000). ${ }^{8}$ This is because water collected over larger watersheds will have to flow over a larger area before it is collected and a large part will be lost in small puddles and depressions, as soil moisture and evaporation. Much before irrigated crop production, semi-arid India needs drinking water for its dispersed rural population during the nine months without rainfall. Many Indian observers think that the answer is not piped water supply schemes but decentralised rainwater harvesting. Agarwal's Centre for Science and Environment has estimated the average area needed per village to capture sufficient water to meet every household's drinking and cooking water requirement in the various regions with varying climate, precipitation and demographic conditions. The average for India as a whole was all of $1.14 \mathrm{ha}$ village in a normal year and $2.28 \mathrm{ha} /$ village in a drought year!

\section{Organisation of the water sector}

Developed-country water sectors which have evolved over decades of public intervention tend to be highly organised and formalised with the bulk of the water delivered-and most of the users served - by "service providers" in the organised

${ }^{8}$ For instance, Agarwal cites evidence from the Negev desert in Israel to show that 3000 micro-catchments of 0.1 ha capture 5 times more water than a single catchment of 300 ha, and this multiple increases in a drought period (p: 9). He also cites results by Michael Evanari, an Israeli scientist that show that 'While a 1 ha watershed in the Negev yielded as much as $95 \mathrm{~m}^{3}$ of water per ha per year, a 345 ha watershed yielded only $24 \mathrm{~m}^{3} / \mathrm{ha} /$ year. In other words, as much as 75 percent of the water that could be collected was lost. This loss was even higher in a drought year.' Agarwal cites Evenari: "...during drought years with less than $50 \mathrm{~mm}$ of rainfall, watersheds larger than 50 ha will not produce any appreciable water yield while small natural watersheds will yield $20-40$ $\mathrm{m}^{3} / \mathrm{ha}$, and micro-catchments (smaller than $0.1 \mathrm{ha}$ ) as much as $80-100 \mathrm{~m}^{3} / \mathrm{ha}$." 
sector. In low-income countries, a vast majority of water users-the poorest ones-get their water directly from rain and from local private or community storage without any significant mediation from public agencies or organised service providers. The notion of water service providers is alien to a majority of rural South Asians and Africans. As a society evolves and its economy as well as water sector mature, the bulk of the water delivered to ultimate users is produced, developed, planned, allocated-in general, managed--by formal organisations, businesses or utilities. In Israel, for example, 70 percent of the water supply in the country is managed by Mekorot, a state-owned water company that operates the National Water Carrier-the pipeline system that moves water from Lake Galilee to the Negev desert, and is in urban water retail, desalination and sewerage treatment businesses (Saleth and Dinar 2000:185). When the bulk of the users and uses are served through the formal sector, resource governance becomes feasible, even simple. If a basin management regime wants to increase the water price to domestic users by 5 percent, or make a law intended to change the way business is done, it can do so with the confidence that it will stick. But this is not true when the bulk of the water users and uses are served by an informal sector where "service providers" are not even registered.

In comparing the Australian success with containing agricultural pollution of water with the Chinese situation, Hu (1999:327) laments that the small number of large Australian farmers are served by a range of local organisations--such as sugar, rice, cattle associations--which serve as vehicles not only for new knowledge and technical advice but also for implementing new rules and laws; but in China, "given the small scale of farming units and the large number of farmers, it is difficult to control chemical and pesticide application, removal of vegetation, erosion and water resource exploitation." In South Africa, over 90 percent of water is managed by formal organisations, including the Water Boards, but 90 percent of rural people, the black irrigators in former homelands are almost wholly in the informal sector, far out of the reach of the public systems.

Ignoring the scale and complexity of dealing with the informal water sectors in the developing world can lead to misleading analysis. In the perspective of Saleth anorDinar (2000: 186), for example, the institutional reform challenge in South Africa "lies in translating the provision of its water law and water policy without creating much uncertainty among private investors." In our view, these are easily done; the real challenge the government of South Africa is struggling with is of reaching the reform to the black communities in the former homelands, who operate in the informal water sector. And hard as the government is trying, this is not proving to be easy. About the process of Catchment Management Agency (CMA) formation in Olifants, South Africa, Merrey (2000:9) writes:

"... rural communities were unaware of the provisions of the new water law and the CMA process, despite the efforts to inform people and offer them opportunities to express their views. Small-scale farmers had not heard about the CMA.... [But] the Irrigation Boards providing water to large commercial farmers were participating actively in the process..." 
Small number of large stakeholders are easy to work with; the ball game changes fundamentally once we have to deal with a huge number of tiny stakeholders.

One way the informal sector can be "formalised" is through grassroots user organisations; and the global Irrigation Management Transfer (IMT) initiatives to organise irrigators into water user associations is partly motivated by the need to bring them into the formal sector. But in this too, small number of large users in the developed world have an advantage over large numbers of small users in the developing world. All manner of user associations form spontaneously in countries like the USA and Australia. These institutional models are constantly being tried out in developing countries but, here, these generally break down when faced with large numbers of small stakeholders who face such diverse constraints in their livelihood systems that they are at best apathetic towards each of them.

Thus, for example, irrigation management transfer to Water User Organisations has unambiguously succeeded in the USA, New Zealand, Colombia, Turkey, and Mexico, all situations of medium to large commercial or export farmers who run their farms as wealth-creating enterprises. In contrast, nowhere in low-income Asia, barring a few "islands of excellence," including the much-researched Philippines, has IMT held out the promise of long-term sustainability. White commercial farmers in South Africa took to Irrigation Boards like ducks to water; in African smallholder black irrigation schemes, there seems little chance that IMT will take off at all unless it is preceded by a wide-ranging intervention to make smallholder farming itself viable (see e.g. Shah, van Koppen, Merrey, de Lange, and Samad 2000).

One standard refrain of institutional discussions in the water sector is get water law and get it "right." It is often the case, however, that the problem is not passing a law but in enforcing it in a society with a large number of tiny stakeholders operating in the informal sector with little or no linkage with meso- and macrolevel resource governance structures. This is why many governments in Asia readily pass Acts but spend years before converting these into laws.

There are also cases of countries which have passed laws, and these have come totally unstuck. Sri Lanka has been debating a water law-which has "all the right ingredients" (Saleth and Dinar 2000)--since the early 1980s but is yet to enact it. This is presumably because it is difficult to figure how to make all the "right ingredients"--water permit systems, full-cost pricing, water courts, explicit water policy statement-actually work in ways that make significant difference to the management of water resource in a country where 50-70 percent of the rural people acquire their water not through water supply service utilities/ companies but straight from nature or from local storage in small community tanks.

India adopted a water policy in 1987; but nothing changed as a consequence; and it is now working on a new one. Many Indian states have likewise been debating groundwater laws for 30 years; a dozen or so drafts are in circulation; the legislative assembly of Gujarat, the state with most severe groundwater overdraft problems, passed a bill as far back as in 1974; but the Chief Minister refused to make it into a law. And his reasons were convincing: firstly, he was unable to see how the law could be effectively enforced on a million small private pumpers scattered throughout 
a huge countryside; secondly, he was certain that it would become one more instrument of rent-seeking for the local bureaucracy (Shah 1993).

"Get the price right" is another old prescription to make water an economic good. Now that water scarcity in many parts of the world is real, it would be naive to question the value of pricing, not so much for revenue collection but to signal the scarcity value of water to users. There can be no serious debate on whether the view of water as a "scarce but free" resource is tenable in today's context. The real issue is making the price of water stick in a situation where a majority of users are in the informal sector and do not go to anyone except the rain-gods for getting their water.

Even in canal irrigation systems in South Asia, which are in the formal sector, many political leaders and senior administrators would become open to volumetric pricing of water to promote efficient use, if only the logistics of doing so were simple and cost-effective, what with the large number of small irrigators in the commands of Asian systems. After all, paying high prices for high quality irrigation service is common for millions of resource-poor buyers of pump irrigation in India, Pakistan, Bangladesh, and Nepal; but most people would avoid paying the full-cost price if not paying were an option, as is the case in many developing country water sectors.

That high transaction cost of monitoring water use and collecting water charge is the central issue in water pricing, rather than the politicians' propensity towards giving away largesse, will soon be evident in South Africa, where the new pricing policy will be easy to enforce on large commercial farmers, for whom the transaction cost of monitoring and collection will be low, rather than areas of black irrigation, which represent the developing-country picture in general, dominated as these are by large numbers of small users.

Developed-country institutions have not solved the problem of serving or regulating large numbers of small users particularly well; indeed, they have not yet found satisfactory ways of dealing with moderate numbers of large users. In New South Wales, Queensland and Victoria, the existing law confers on every occupier of land the right to take and use water for domestic consumptive purposes, watering stock, irrigating home gardens and non-commercial crops on a maximum of 2 ha (Hatton MacDonald and Young 2000: 24). If this exemption were applied to India, it would cover over 80 percent of all land and over 90 percent of all people; and in South Africa, it would cover 90 percent of all users though only 10 percent of land and water. In South Asia, South-East Asia and North China, groundwater is the most valuable and threatened resource; protecting ground-water from over-development is probably among the top three priorities in this region; yet doing so is proving to be a challenge precisely because groundwater is in the informal sector.

In the question of how best to deal with South Asia's 20 million tubewell owners in the informal sector, the experiences of Murray-Darling or Mississippi do not have many practical lessons to offer. Even in "highly evolved" river basins, sustainable management of groundwater is at best problematic, and at worst, as hopeless as in India and Pakistan. Murray-Darling has tried groundwater regulation but it is not certain if it has worked. Access to groundwater in New South Wales is regulated by licences under the Water Administration Act of 1986; however, 
"over much of New South Wales, undeveloped licences were not cancelled. In retrospect, this has proved an administrative disaster as, in a number of areas, the total volume of licences issued is well in excess of estimated sustained yield." (Hatton MacDonald and Young 2000:23).

In California's Central Valley, groundwater over-exploitation is a 60-year-old problem; yet in his case study of basin management, Svendsen $(2000)$ concludes that

"Groundwater is the most lightly planned and regulated segment of the state's water resources. There is little control over abstractions and, on average, the state is in a serious overdraft situation."

Even in middle-income countries, where major institutional reforms have been initiated in recent years, groundwater over-exploitation has defied solution. Spain, one of the European countries that suffer agricultural over-exploitation of groundwater, has instituted sweeping reforms that will affect surface water but have little to do with groundwater (Saleth and Dinar 2000). Mexico's aquifers too are amongst the most over-developed; IWMI researchers based in Guanajuato state, one of Mexico's agriculturally dynamic regions, found water tables in 10 aquifers they studied declining at average annual rates of 1.79-3.3 m/year during recent years (Wester, Pimentel and Scott, 1999:9). An institutional solution is being tried here; the establishment of Aquifer Management Councils called COTAS (Consejos Técnicos de Aguas) in Mexico as part of its water reforms and under the new Mexican water law are a notable development. IWMI researchers in Guanajuato are, however, sceptical: "...several factors bode ill for their (COTAS') future effectiveness in arresting groundwater depletion..."

Finally, for top echelons of national decision-makers, it is always easy to take hard decisions, which do not affect a large proportion of a nation's population in a seriously adverse manner. Political leaders and water-sector leaders in emerging economies constantly face pressures to be myopic and adopt postures that are at odds with the ideal of integrated RBM. The most powerful and compelling pressures emerge from their own internal social realities. In low-income agrarian societies like in South Asia and much of Africa, food security and poverty alleviation will continue to remain prime concerns for decades to come.

When several poor states are involved in a basin-such as India, Nepal, and Bangladesh in the Ganga-Meghana-Brahmaputra basin, or the Central Asian states in the Aral Sea-co-ordinating mechanisms tend to operate at sub-optimal levels because national leaders are under pressure to maximise their national interests. It has been argued that the Aral Sea crisis is the outcome of the compelling need of the political leaders in the Central Asian states to ensure food security as well as water-intensive cotton cultivation for export, both at once; and a major move to reverse the desiccation of the Aral Sea, the Amu Darya and the Syr Darya, will have to wait until something changes the dominant perception of the political leadership in Turkmenistan and Uzbekistan that cessation of cotton monoculture will have politically and socially destabilising consequences. 


\section{Stage of socio-economic development}

What factors might influence the pace of institutional change in developing-country water sectors? Saleth and Dinar (2000) suggest that as water scarcity intensifies, opportunity costs imposed by missing or malfunctioning institutions will increase and transaction costs of institutional change will decline, which together will determine the pace of institutional change in developing countries. A competing hypothesis is offered by the application of Kuznets' curve to natural resource management by societies. Recently, there have been attempts to fit an environmental Kuznets curve to deforestation using cross-country data (Bhattarai and Hammig 2000).

The environmental Kuznets curve (ECC) poses an inverted $U$ relationship between economic growth and environmental degradation (Figure 4). The core hypothesis is that, as economies grow, they use natural resources as a factor of wealth creation; but as per capita real income grows, demand for environmental amenity grows and there is greater demand and support for environmental protection.

Although the empirical results of some of this econometric work are far from conclusive, intuitively, it seems compelling to suppose that the income elasticity of demand for environmental amenity is lower at low per capita incomes (as in Bangladesh and Burkina Faso) than at high per capita incomes; and therefore, that highly evolved economies of the Western world would have greater demand, capacity and collective will to fix the environmental problems from natural resource mismanagement than low-income emerging economies. In many Western countries, where per capita income growth to present levels took 200 years or more, the ECC-effect too took centuries to work out. Historical evidence suggests deforestation in Europe was at its peak at the time of the Industrial Revolution; and the area under forests began to increase long after economic prosperity ensued (Bhattarai and Hammig 2000).

Figure 4: Relationship between level of economic growth and natural resource degradation

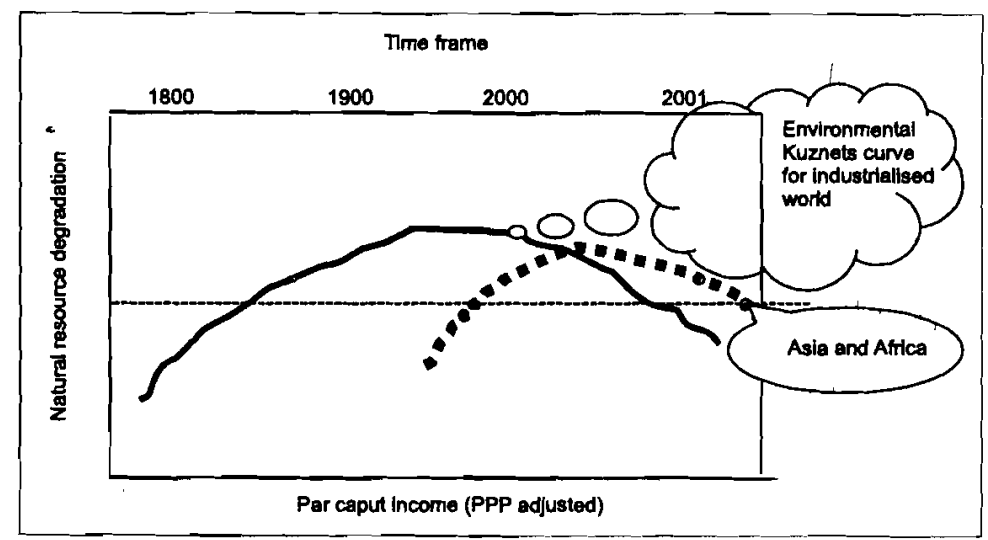


Much the same relationship seems to hold in the case of water resource management, too. Countries with highly developed water institutions are also those which have evolved industrially. In contrast, it is difficult to find a low-income agrarian society, which has highly developed water institutions. Interestingly, some sketchy evidence suggests that the period of decline followed by upswing gets telescoped in economies like Japan and Taiwan that have grown their industrial output and employment rapidly over a relatively short period.

In Table 1, we present the data set for 57 countries organised around their per capita water and arable land availability. The figures alongside the country names are their respective per capita $\mathrm{CO}_{2}$ emissions, which is one of the best co-relates of GDP per capita as well as Human Development Index. Mean per capita availability of water and arable land along with $\mathrm{CO}_{2}$ emission is used to divide the countries into eight categories

Countries in categories $\mathrm{B} 1, \mathrm{C} 1$ and $\mathrm{D} 1$ are poor in water and/or arable land resources; but these are rapidly becoming post-agrarian societies where pressure on water and land from irrigated farming will rapidly ease. The social and economic costs of fixing water mismanagement in these countries already are or will soon be within acceptable limits.

It is notable that A1 represents the category of countries from which most models of effective water institutions emerge, and these are offered to countries in D2 category which have the least water, land and $\mathrm{CO}_{2}$ emissions. $\mathrm{A} 1$ are amongst the best endowed countries with both water and land; as a result, despite being highly industrialised (as indicated by their high $\mathrm{CO}_{2}$ emissions), these still have large, wealth-creating agriculture and agro-industries sectors that absorb a very small proportion of their populations.

In D2 category, poor land and water resource endowments combine with high population pressure; but ironically, their most critical problem is their low $\mathrm{CO}_{2}$ emission. Industrial growth, urbanisation and transfer of people from agricultural to off-farm livelihoods seems the only way pressure on land and water will ease. Many of these countries will, over the coming decades, more likely take the Kuznets-curve route that Japan and Taiwan took than the one that the Australia and USA took.

In Taiwan, where rapid industrial growth and urbanisation have resulted in 40 percent decline in irrigated areas over recent decades, the popular outlook towards water management issues has undergone fundamental transformation. Over 90 percent of Taiwan's irrigators have become part-time farmers, and income from industrial employment far outweighs agricultural incomes; there have been major increases in demand for environmental amenity and in the touristic value of former irrigation structures; all these have resulted in substantial private initiatives and investments in improving water quality and aquatic ecology. Taiwan has amongst the highest population densities we find anywhere in the world; yet its water institutions will soon approach those in high-income western countries rather than low-income Asian countries, which share high population density with Taiwan. 


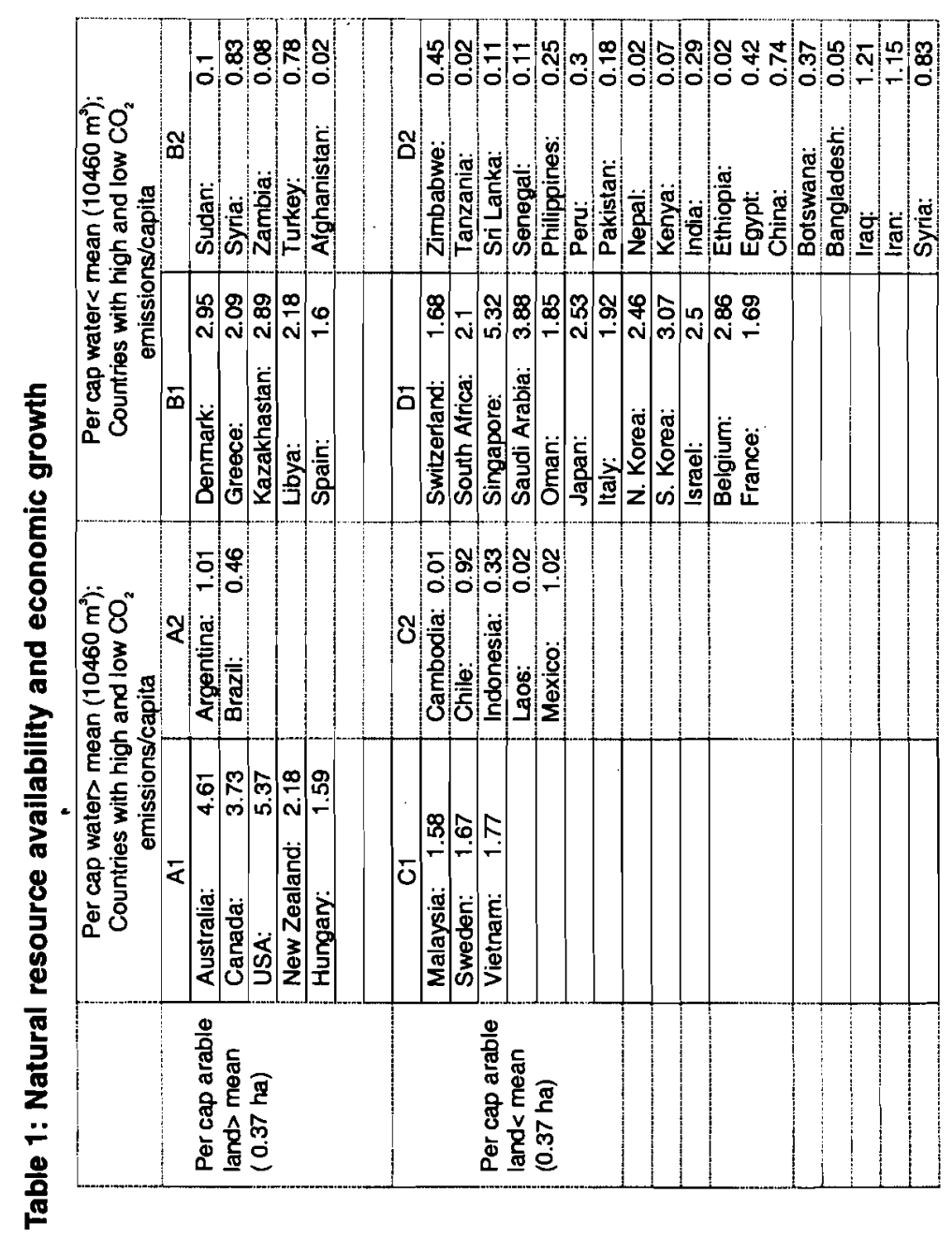

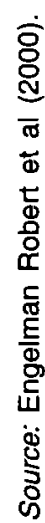


The Kuznets curve hypothesis looks at the relationship only from the angle of demand for environmental amenity. But there is also the supply side to it; much larger volume and quality of resources are applied to natural resource management in high-income countries than in low-income countries. Consider the budget of the water departments: California State Department of Water Resources has 2000 employees, mostly professionals, who operate an annual budget of US\$1 billion (Svendsen 2000); Gujarat Department of Water Resources probably employs as many engineers but operates a budget of less than US\$10 million. The upshot of this discussion is that, over a decadal timeframe, economic growth is probably both the cause as well as response to the problem of natural resource mismanagement; and, if the experience of Japan and Taiwan is any guide, the period over which the interaction between the two plays out need not run into centuries as it did in the case of Europe, but it can be telescoped from centuries to decades.

\section{Conclusion}

In this paper, we have made an attempt to explore why efforts to transfer the institutional models of river-basin management from developed countries to developing ones have not met with desired success. The contexts in which reforms are tried in developing countries are vastly different-in their hydrologic and climatic conditions, in their demographics, in their socio-economic conditions as well as in the way their water sectors are currently organised-from the context of the countries in which the models first succeeded. Successful institutional reforms in the water sector world-wide have tended to have common over-arching patterns. They have focussed largely on management of surface water bodies; they have aimed at improving the productivity of publicly diverted large water bodies; they have largely ignored groundwater and have not had to contend with dominant informal water sectors; they have centrally been about "blue water" productivity and have largely ignored "green water."

The problems that successful institutional models have resolved-water quality, wet lands, sediment build up in the upper parts of the river, maintaining navigation use, dealing with occasional floods-are often not of paramount interest in the developing country contexts. And the problems that developing countries find critical and insurmountable have either remained unresolved in developed-country river basins, such as groundwater over-exploitation, or are rendered irrelevant by their evolutionary process, as in using irrigation as a means to provide poor people with livelihoods and food security. This does not by any means imply that developed-country experience has no lessons to offer to the developing world; drawing such a conclusion would be naïve in the extreme. What it does mean, however, is that imposing institutional models uncritically in vastly different socioecological contexts can be dysfunctional and even counter-productive.

What it also means is that we need to take a broader view of institutional change. An extraordinary aspect of the institutional discussion in the global water sector is how very narrowly it has focussed on things that governments can do: make laws, set up regulatory organisations, turn over irrigation systems, and specify property rights. A recent review of institutional changes in the global water sector in 11 countries by Saleth and Dinar (2000), for example, treats water law, water policy 
and water administration, as the three pillars of institutional analysis. This makes water purely the government's business, quite contrary to the slogan popularised by the World Water Council to make "Water Everyone's Business!" If institutional change is about how societies adapt to new demands, its study has to deal with more than what just the governments do; people, businesses, exchange institutions, civil society institutions, religions and movements-all these must be covered in the ambit of institutional analysis (see, e.g. Mestre 1997 cited in Merrey 2000:5).

Which elements of the Murray-Darling experience can be sensibly applied in which developing-country context is certainly an important and interesting analytical enterprise; but equally, or even more, important is the need to listen to voices from the grassroots. If people living, for example in the Deduru Oya basin in Sri Lanka, are facing water scarcity, they are sure going to begin to do something about it; likewise, if the government of South Africa withdraws from the management of smallholder irrigation schemes in the Olifants basin, the smallholders will soon respond in some way. What institutional reform makes best sense in Deduru Oya or Olifants should best emerge from understanding the respective realities of these basins; a broad understanding of what has worked elsewhere including in the developed world might offer a good backdrop to the design of institutional interventions. But it might be unrealistic to expect much more; copycat institutional reform would be outright disastrous.

In understanding how societies adapt their institutions to changing demands, Nobel Laureate Oliver Williamson (1999) suggests the criticality of four levels of social analysis as outlined in Figure 5. The top level is referred to as the social embededness level where customs, traditions, mores and religion are located. Institutions at this level change very slowly because of the spontaneous origin of these practices in which "deliberative choice of a calculative kind is minimally implicated." At the second level-where the institutional environment of a society is involved-evolutionary processes play a big role; but opportunities for design present themselves through formal rules, constitutions, laws, property rights; the challenge here is getting the rules of the game right. The definition and enforcement of property rights and contract laws are critical features here. Also critical is understanding how things actually work-'warts and all'-in some settings, but not in others.

However, it is one thing to get the rules of the game (institutional environment) right; it is quite another to get the play of the game (enforcement of contracts/property rights) right. Which leads to the third level of institutional analysis: transaction costs of enforcement of contracts and property rights, and the governance structures through which this is done. Governance-through markets, hybrids, firms, bureausis an effort to craft order, thereby to mitigate conflict and realise mutual gains; and good governance structures craft order by reshaping incentives, which leads to the fourth level of social analysis-getting the incentives right.

Discussion of water policy and institutions in the developing-country context has focussed a g-reat deal on levels 2, 3 and 4 and little on level 1; more, it has tended to underplay the interactions between levels. Many populous developing countries will feel a lot wiser about IRBM if we learn more about how level 1 operates in their respective contexts and how the interaction between 2 and 3 , and 3 and 4 can 
Figure 5: Four levels of institutional change that explain how societies adapt to new demands

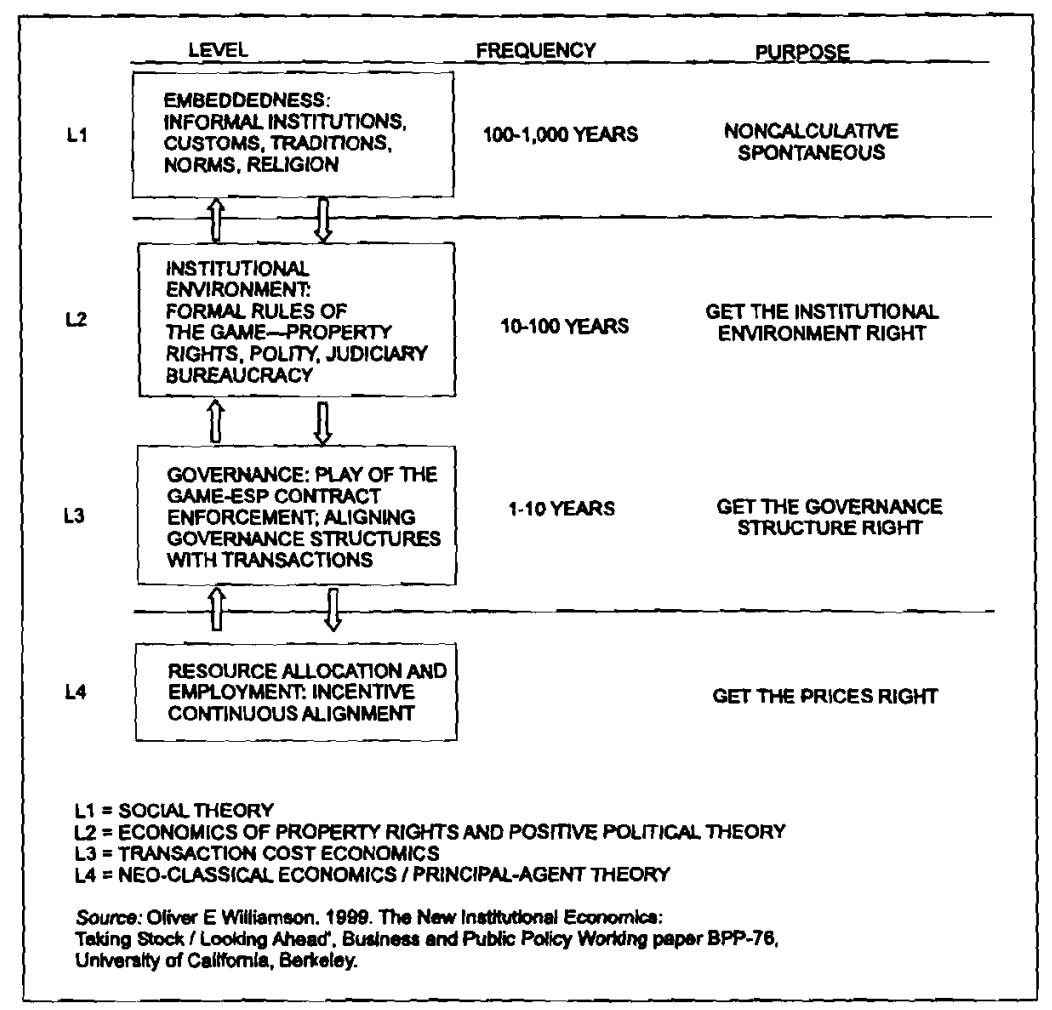

work better. How to create property rights that affect users' behaviour is more important than exhortations that clear property rights be created; understanding how to enforce a groundwater law meaningfully on 20 million private pumpers scattered throughout the South Asian countryside is more helpful than pushing a groundwater law; how to monitor water use and collect canal irrigation charges cost-effectively is more in order than discussing whether irrigation subsidies should be eliminated. 


\section{Acknowledgements}

This work is supported by a Research Grani from BMZ (Germany's Ministry of Economic Co-operation) to IWMI to study Institutional Support Systems for Water Management in Water-stressed River Basins.

The authors gratefully acknowledge the contributions of colleagues in developing these ideas: Matsuno for supplying literature on water management institutions in Japan; Hilmy Sally for help with an Excel chart; David Molden for discussions on water accounting; Randy Barker for drawing attention to Williamson's excellent article; Madhusudan Bhattarai, from whose work the ideas on Environmental Kuznets Curve are drawn; Frank Rijsberman for a stimulating discussion in a car ride in Hyderabad on what are the meaningful issues in the debate on water pricing; Tissa Bandaragoda and M Samad for many interesting discussions on basin management research; and Doug Merrey for introducing the author to the field of IRBM. The authors own the responsibility for the argument, with all its limitations and flaws.

\section{Bibliography:}

Agarwal, Anil. 2000. Drought? Try capturing the rain. Delhi: Centre for Science and Environment.

Bhattarai, M.; and M. Hammig. 2000. Institutions and the environmental Kuznets Curve for deforestation: A cross-country analysis for Latin America, Africa and Asia. Forthcoming in World Development.

Birch, Alfred; and Paul Taylor. 1999. International mentoring; Application of Australian experience for Sri Lankan water sector reforms under Technical Assistance of the Asian Development Bank. Water International, vol. 24, no 4, pp 329-340.

Engelman, R.; Richard P. Cincotta; Bonnie Dye; Tom Gardner-Outlaw; and Jennifer Wisenewski. 2000. People in the balance: Population and natural resources at the turn of the Millennium. Washington, Population Action International.

Global Water Partnership. 2000. Integrated Water Resources Management. Stockholm: Technical Advisory Committee of GWP.

Hatton MacDonald, Darla; and Mike Young. 2000. A case study of the MurrayDarling Basin: Draft preliminary report. Sydney: CSIRO, prepared under commission for IWMI.

$\mathrm{Hu}$, Xiandeng. 1999. Integrated Catchment Management in China: Application of the Australian Experience. Water International, vol. 24, no 4, pp 323-328.

Hunt, Chris. 1999. Transposing of water policies from developed to developing countries: The case of user pays. Water International, Vol. 24, No 4, pp 293306.

Jacobs, Jeffery. W. 1999. Comparing River Basin Development Experiences in the Mississippi and the Mekong. Water International, vol. 24, No. 3, September. 
Malano, Hector; Michael Bryant; and H Turral. 1999. Management of Water Resources: Can Australian Experiences be transferred to Vietnam? Water International, vol. 24, no 4, pp 307-315, December.

Merrey, Douglas. 2000. 'Creating institutional arrangements for managing waterscarce river basins: emerging research results. Paper presented at the session on 'Enough Water for All', at the Global Dialogue on the Role of the Village in $21^{\text {st }}$ Century: Crops, Jobs, Livelihoods, August 15-17, 2000, Hanover, Germany.

Mostert, E.; E. van Beek; N.W.M. Bouman; E. Hey; H.H.G. Savenije; and W.A.H. Thissen. 1999. River basin management and planning. Keynote paper for International Workshop on River Basin Management, The Hague, 27-29 October, 1999.

Saleth, Maria; and A. Dinar. 2000. Institutional changes in global water sector: trends, patterns and implications. Water Policy 2 (2000) 175-199.

Shah, Tushaar. 1993. Water markets and irrigation development: political economy and practical policy. Bombay: Oxford University Press.

Shah, Tushaar; B. van Koppen; Douglas Merrey; Marna de Lange; and M. Samad. 2000. Institutional alternatives in African smallholder agriculture: lessons from international experience in irrigation management transfer. Paper presented at National Policy Workshop on Irrigation Management Transfer and Rehabilitation of Smallholder Irrigation Schemes. June 21, 2000 at Hazy View, Mpumalanga, South Africa.

Sutcliffe, J. V. (1995). Hydrology in the developing world. In G.W. Kite (ed.) Time and the River: Essays by Eminent Hydrologists. Saskatoon, Canada: Water Resources Publications

Svendsen, Mark. 2000. Basin management in a mature closed basin: The case of California's Central Valley. In : C. L. Abernethy (ed.): Intersectoral management of river basins. IWMI, Colombo, Sri Lanka and DSE, Feldafing, Germany.

Williamson, Oliver E. 1999. The new institutional economics: Taking stock/looking ahead. Business and Public Policy Working paper BPP-76, University of California, Berkeley. 